\title{
A Framework for Conceptualizing Customer Experiences Management in the Hotel Industry
}

\author{
Bachruddin Saleh Luturlean \\ School of Postgraduate Studies, \\ Universitas Pendidikan Indonesia \\ 40154 Bandung, Indonesia \\ bachruddin_saleh@yahoo.com
}

\author{
Grisna Anggadwita \\ School of Economic and Business, \\ Telkom University \\ 40257 Bandung, Indonesia \\ grisnamailbox@yahoo.co.id
}

\begin{abstract}
The hospitality industry has an excellent investment potential. The tourism sector is closely related to the hospitality industry, where the growth of the hospitality industry cannot be separated from the development of the tourism sector, and vice versa. The rapid development of the hospitality industry leads to the emergence of intense competition in attracting guests to stay as well as to take advantage to the facilities available at the hotel. Every hotel aims to provide the customer experience in order to create customer loyalty that have an impact on the level of customer revisit intention. In this paper, we provide an overview of the existing literature on the management of the customer experience and expand the process of creating a customer experience from a managerial perspective. This paper proposes a conceptual model, which discusses management strategies as a determinant factor of the customer experience. In addition, this paper discusses the factors of customer experience management, where the customer attitude and social environment (trend and lifestyle) also influential in shaping the customer experience. Customer experience management is also seen based on strategic perspective with a focus on issues such as how and to what extent an experience-based business can create growth. This study provides the conceptual framework of Customer Experience Management (CEM) as the company's new attempts to understand and manage the customer experience and thus contribute both to academic research and managerial implications.
\end{abstract}

Keywords- CEM; customer attitude; customer loyalty; hospitality industry; social environment

\section{INTRODUCTION}

The rapid development of hospitality industry leads to the emergence of intense competition in attracting guests to stay as well as to take advantage of the facilities at the hotel. To face the competition, companies are required to develop themselves and appear more competitive by providing attractive offers to attract and retain potential customers consisting mostly of businessmen and tourists. The hotel management should be able to make strategic planning and the right marketing strategy to be able to compete in the present and future. Thus, every company must be able to create business differentiation with other business. The activities that can be done to differentiate themselves from competitors by triggering a memorable customer experience, a process in which multiple stimuli tangible and intangible can interact [14]. Today, creating a superior customer experience seems to be one of the main goals in the hotel industry. According to [5], Starbucks's success is based on creating a unique customer experience for their customers. In addition, the research conducted by [6], identified that the customer experience as a key factor for companies to use in building brand loyalty, channel and service.

Ref [7] and [8] examined the customer experience when shopping at retail. Other authors examine the impact of the promotion [9], pricing and competitive effects [10], merchandise management [11], the supply chain [12], and location. Ref [13] explained that the experience of the quality of service, satisfaction experiences, experiences that shape a positive value, and the image of a tourist spot have a relationship with revisit intention. Companies that are able to compete are companies whose products or services can be accepted by customers. The purpose of a business is to create and maintain consumer [14], so that marketers must be able to create a loyal customer to the company.

Academic literature related to the customer experience management in the hotel industry is still quite limited, so there is domain of interest for further investigation. This study aims at establishing a conceptual framework based on the theory that it can serve as a stimulus and a foundation for further research. Figure 1 below is a conceptual framework that forms the model of the customer experience in the hotel industry. This paper discusses the customer experience management; and builds conceptual models as well as strategy factors for creating a customer experiences that ultimately have an impact on consumer satisfaction, consumer value, and revisit intention. In addition, there are other factors that influence directly in shaping the customer experience, as well as the customer attitude and social environment. Seeing the current phenomenon, a dynamic social environment is also proved to influence on trends and lifestyle.

This paper has identified five strategy factors in the customer experience management, where every strategy factor has antecedents that influence directly in creating a customer experience. Five strategy factors are the product/service, Service interface, price and promotion, communication channels, and brand relationship. 


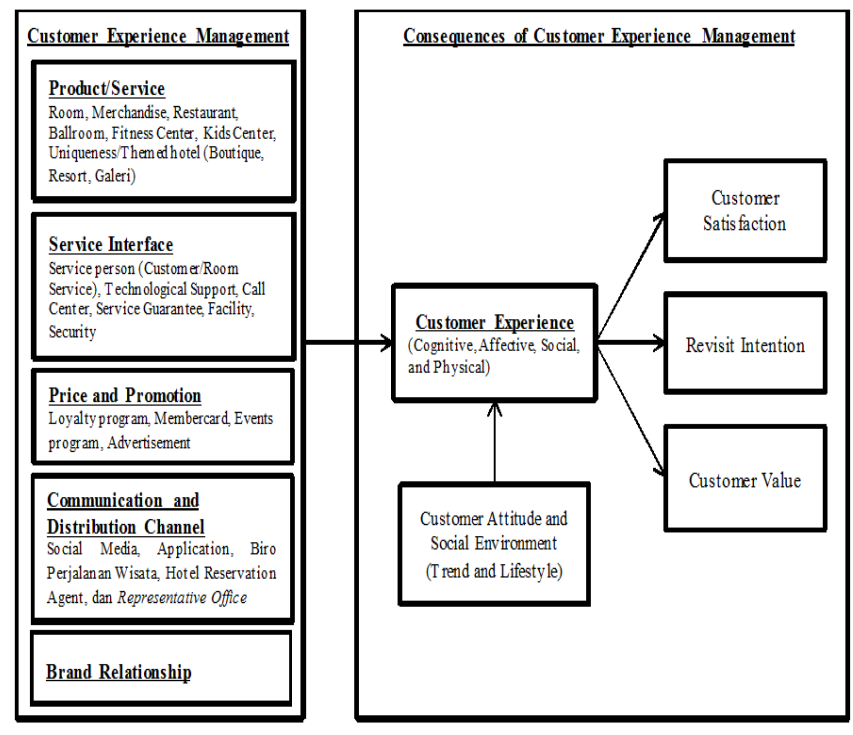

Figure 1. Conceptual Model of Customer Experience Management

\section{Hotel MARKETING}

According to The American Hotel and Motel Association (AHMA) as cited by Steadmon and Kasavana, the hotel can be defined as a building that is managed commercially by providing accommodation facilities to the public with service facilities to eat and drink, room service, service luggage, washing clothes. Additionally, the customers can use the facilities or furniture, as well as enjoy the decorations in it. Marketing services of the hotel consist of several activities that aim to attract potential customers by giving motivation so that they are interested in buying the products and services of the hotel. According to [15], hotel marketing is an activity that uses strategies and tactics, which is planned in a way to convey the "story" of services a hotel can give, by providing stimulus passionate on guests to choose the message that the hotel compares to another choice of the competitor hotels. Another definition is proposed by [16], hotel marketing is knowledge to please the guests and from that activity, the hotel would gain profits. Therefore, Kotler mentioned it as sensitive serving and satisfying the human need [17]. Ref [18] stated from the service industry point of view, hotel marketing can be defined as processing food, beverage, and hotel accommodation into a demanded product by adding value through service and presentation.

\section{Customer EXPERIENCE MANAGEMENT}

Customer experience management strategy is to create value both to customers and companies. Customer experience management is different from customer relationship management by focusing on the customer experience when enjoying and feeling the services that the company provides. According to [19], "Customer Experience Management $(\mathrm{CEM})$ is the process of strategically managing a customer's entire experience with a product or a company". In this research, CEM is a strategic process in managing or implementing customer experience in a product or service.
CEM is a management process that is completely focused on the customer and process-oriented.

According to [20], CEM provides insight to generate Return on Customer (ROC). It requires a different approach, which markets products with charted on the lifestyle and life stage customers. According to [21], a complete experience can be gained by customers through five major components that combine distance dimension between the products, services, brands, channels and promotion. The experience is formed by the components that help the company avoid mistakes and learn how to expand and to enrich the customer experience.

\section{A. Product/Service Experience}

According to [22], the product is all that can be offered to the market to be considered, possessed, used, or consumed, which can satisfy the desires or needs of the consumer. The difference between products and services as being sought by customers are increasingly difficult to distinguish. Both components are complementary to each other as a unity that customers expect when going to consume a product. Products are designed to give the customer experience while taking it. If the customer is satisfied with what is obtained from the function of the product, the customer will then automatically return to consume these products. In positioning a product, the main thing is the image formation that marketers want to create in the minds of consumers [23].

The hotel industry is a business that is engaged in the service. However, the hotel management can also provide customers experience by providing a variety of different facilities and merchandise. The hotel management should be able to do business differentiation while focusing on customer needs to be able to follow the changes in today's dynamic environment. Some of the facilities that can be provided by hotel management to increase customer experience is the availability of fitness center and kids center. In addition, the hotel management should also be able to display their identity by applying concepts themed hotels such as resort, boutiques, and galleries. Themed hotel concept can also be a product / service that has a sale value for its customers.

\section{B. Service Interface Experience}

Service interface is one of the strategies factors in managing the customer experience, which the hotel management provides the services to be directly enjoyed and perceived by customers. Customers experience a variety of negative emotions when there is a failure of service, causing a bad experience for its customers. One of the hotel management's commitments is to provide the best service to its customers with a service guarantee.

Currently, service-based interface technology is already widely used by various companies including the hotel industry. Some examples of technology-based service provided by the hotel management are free $\mathrm{Wi}-\mathrm{Fi}$, cable TV, and others. Several previous studies relate to service-based interface technology, researching how customers rate the quality of services delivered through the website (e-service) and developed a scale to measure the construct [24-26] and customer interaction with technology-based self-service options [27]. Service interface refers to the dynamic changes of services and information that occur between the customer and the company individually through offline and online. 
Designing and managing a service interface are a complex task. They are divided into three interactions, namely: Face to Face that includes changes and interactions that occur directly; Personal but Distance that include changes and interactions that occur via telephone, fax, mail and e-mail or via the Internet; and, Electronic that covers changes and interactions in an e-commerce site, via e-mail or a Short Message System (SMS).

Customers who feel the comfort of the services directly have a positive impact both on the quality and overall customer satisfaction. This ultimately leads to positive wordof-mouth [28]. Thus, the service person must really have the ability to serve customers well and responsive. In addition, to provide a better customer experience, company should try to incorporate elements such as design services and facilities that meet customer needs. Another service interface that should be provided by the hotel management is a call center for customer interaction facilities with the hotel management and security. Service interface has a major influence on the experience that leads to the experience of brand recall, resulting in the perception that ultimately shapes attitudes.

\section{Price and Promotion Experience}

Price in the hotel industry is one of the unique elements, which for some hotel segments; price is not only a consideration in using the services of the hotel but also by considerations of comfort. Hotel segment is divided based on star level and the effect on the prices offered. Price is one of the marketing concept that is quite sensitive because it relates to the size of the costs incurred by the customer and the benefits gained by customers after consuming. The hotel management should prepare a strategy program in delivering the customer experience for the price offered.

The literature on integrated marketing communication is very broad, but research relating to the marketing of the hotel is very specific. Some researches suggest that the promotion of the sale of goods may increase substantially [29-30]. The hotel industry also needs the concept of marketing promotions to increase sales. The promotion process that is still in use today is through advertisements in various media, but today's dynamic environment leads the hotel industry to be more aggressive in making the concept of promotion in order to attract more consumers. Some promotional programs recommended in this paper are a loyalty program and member card to bind the customers. Every customer who becomes member hotel gets benefits in the form of discounts or other benefits offered by the hotel. In addition, the hotel promotion program can be performed through events program with varying concepts adapted to the target market, such as the availability of space for the mini concert, seminar, or exhibition.

\section{Communication and Distribution Channel Experience}

Alternative channels produce high customer equity and influence the customer experience [19]. Integration of communication channels whether online or offline can present the customer experience in obtaining the information or products/services desired. According to [31] there are five major challenges that must be addressed by practitioners to improve the effectiveness of management of multi-channel customer: (a) data integration, (b) customer behavior understanding, (c) channel evaluation, (d) resources allocation in all channels, and (e) channel strategy coordination.

Ref [12] examined a number of issues for the multichannel hierarchical relationship, where manufacturers and retailers sell through a variety of channels to consumers. Hierarchical of multi-channel relationship causes conflicts that can occur between the channel members, who must compete with one another. A more positive approach would pursue channel structure with mutually beneficial, such as profit sharing [31-32].

Communication and distribution channels are strategy factor that should be the focus of the hotel industry. Communication channels relate to the interaction between the management of the hotel and the customer. Current technological advances affect the trends and lifestyles of people, therefore the hotel management should follow the dynamic changes. Communication channels with the use of technology are performed through social media such as Facebook, Twitter, Instagram, etc. The hotel management also can make official hotel account and interact directly with customers. In addition, today's mobile application platform can be used as communication channel to facilitate customers to obtain information and services from hotel.

Distribution channels are also important strategy factors that should be managed by the hotel management, which present the customer experience to get the products / services with ease. In addition to the application of technology, distribution channels can also be performed through the conventional travel agency, Hotel Reservation Agent, and Representative Office.

\section{E. Brand Relationship}

Brand is one of the important factors as the identity of a company, as well as a name that indicates a person's identity. Brand must have a relationship or involvement with customers, which means that a brand should be able to describe the needs of its customers. The hotel industry also should have a brand that can build relationships with customers. Brand has become more important in the evaluation of the consumer, and on a number of dimensions of emotional appeal, including trust, desire, and sophistication.

Brand must reflect the needs, values and lifestyle of the customer because it will form an emotional bond that develops between people and the brands they purchase. Previous research shows that customer experience has a significant impact on the brand perception of overall customers. Ref [33] and [34] examining the interaction between brand equity and customer equity shows that each can affect the other. In addition, [35] proposed that the mindset of the customer (e.g. awareness, associations, attitudes, attachment and activity) is the main key of brand performance (for example, a premium price, price elasticity, market share, and the success of the expansion).

Brand attributes that lead to the development of customer relationship are not much explored. Ref [36] underlined the importance of aligning the customer experience with the company's brand and demonstrated how this can be achieved. To understand how the customer experience is created, it is important to consider the interaction between the brand and the customer experience. Brand perception can affect the customer experience. 


\section{CUSTOMER EXPERIENCE}

The customer experience is derived from a set of interactions between customer and product, company, or part of an organization, which encourages the reaction. This experience really implies the involvement of customers personally at different levels (rational, emotional, sensory, physical, and spiritual) [37]. According to [38], customer experience is customer internal response and subjective directly or indirectly to the company. Direct contact generally occurs in the process of purchasing, procurement, and service, and is usually initiated by the customer. Indirect contact most often involves unplanned meeting with representatives of the company's products, services or brands and takes place based on word-of-mouth or criticism, advertising, news, reviews and so on.

In academic literature, experience classification consists of sensory, emotional, rational, pragmatic and relational [37]. Ref [39] has identified three categories of instructions including functional, mechanical, and human resource. Functional instructions are in accordance with the technical quality of service, while the mechanical instructions relate to the design and ambient factors such as equipment layout, color, and lighting. The examples of human resource instructions are employee behavior. Some authors such as [40] classifies the customer experience into four parts, including entertainment, education, escapist, and aesthetic. On the other hand, [37] has classified the customer experience into six categories based on the most comprehensive of the customer experience: sensory, emotional, cognitive, pragmatic, lifestyle and relational.

The concept of the customer experience in this study involves cognitive, affective, emotional response, both socially and physically for the customer. The experience made not only by elements that can be controlled (e.g. product / service, service interfaces, price and promotion, communication and distribution channels, and brand relationship) but also by elements that are beyond the control of the hotelier (e.g. customer attitude and social environment).

\section{THE CEM CONSEQUENCES}

\section{A. Customer Satisfaction}

Satisfaction is the result of the positive things reduced by negative things and identified through the gap between customer expectations with customer experience. To discover how to satisfy the customer, companies must break down the components of experience [38]. Customer satisfaction can be influenced by how a company can provide the emotional benefits experience that can be felt by customers when purchasing products/services [41-43]. Thus the customer experience management influences the formation of consumer satisfaction.

\section{B. Customer Value}

Customer value gives an overview of the customers to a company, considers what they want, and believes that they benefit from a product or service [44]. The customer value can form an emotional bond between customers and manufacturers after customers use and feel the value added to the product or service [45]. It is indicated that emotional connection created is based on the customer experience that it can create reciprocal positive impact for customers and industry. Thus, the customer experience has impacts on the creation of customer value.

\section{Revisit Intentions}

According to [46], one of the benefits of customer satisfaction is that it can lead to repeating purchases. The level of customer satisfaction will result in increased customer loyal and result in customers going back to the same place to make repeating purchases. A similar opinion is expressed by [47], when the products / services are able to deliver a positive memorable experience touching the side of their affection, consumers will always remember the products / services when consuming similar products. Customers will become rabid and consciously (or unconsciously) will invite others to consume these products [48].

\section{CONCLUSION}

The hotel industry is a dynamic industry, resulting in competition between companies. Customer experience management as a new concept can be used by companies to retain customers and increase the customer revisit intention. The concept of customer experience is not new; this concept has been used, analyzed, and implemented by many companies. This paper makes several important contributions in research. First, it shows the evolution of the concept of the customer experience in the academic literature. Second, it has highlighted the antecedents of customer experience management through an extensive review of the existing literature. CEM antecedents that have been identified in this paper are: product / service, service interfaces, price and promotion, communication channels, and brand relationship. Hotel that takes into account and implements these concepts can create the customer experience, which ultimately leads to customer satisfaction, customer value, and increasing customer revisit intention. This framework can be used by managers and practitioners as a concept in measuring the customer experience. Further research may be used to conduct an empirical study of the framework that is built in this paper.

\section{References}

[1] A Carù and $B$ Cova. "Revisiting consumption experience: $A$ more humble but complete view of the concept". Marketing Theory, 3(2), 2003, pp. 259-278.

[2] A Carù and B Cova. Consuming experience. London: UK: Routledge, 2007a.

[3] M Healy, M Beverland, H Oppewal, S Sands. "Understanding retail experiences - The case for ethnography". International Journal of Market Research, 49(6), 2007, pp. 751-779.

[4] A Klingmann. Brandscapes: Architecture in the experience economy, Cambridge, MA: The MIT Press, 2008.

[5] J Michelli. The Starbucks Experience: 5 Principles for Turning Ordinary Into Extraordinary. New York: McGraw Hill, 2007.

[6] Badgett, Melody, Maureen Stancik Boyce, Herb Kleinberger, "Turning Shoppers into Advocates", IBM Institute for Business Value, 2007.

[7] Puccinelli, M Nancy, C Ronald, Goodstein, D. Grewal, R. Price, P. Raghubir and D. Stewart. Customer Experience Management in Retailing: Understanding the Buying Process. Journal of Retailing, Vol. 85 (1), 2009, pp. 15-30. 
[8] P C Verhoef, K N Lemon, A Parasuraman, A Roggeveen, M Tsiros, L A Schlesinger, "Customer Experience Creation: Determinants, Dynamics and Management Strategies", Journal of Retailing, Vol.85 (1), 2009, pp. $31-41$.

[9] K L Ailawadi, Kusum, J P Beauchamp, N. Donthu, D. Gauri, V. Shankar, "Communication and Promotion Decisions in Retailing: A Review and Directions for Future Research", Journal of Retailing, Vol.85 (1), 2009, pp. 42-55.

[10] P Kopalle, D Biswas, P K Chintagunta, Jia Fan, Koen Pauwels, B T Ratchford, \& J A Sills, "Retailer Pricing and Competitive Effects", Journal of Retailing, Vol. 85 (1), 2009, pp. 56-70.

[11] M K Mantrala, M Levy, B E Kahn, E J Fox, P. Gaidarev, B. Dankworth, D. Shah, "Why Is Assortment Planning So Difficult for Retailers? A Framework and Research Agenda", Journal of Retailing, Vol. 85 (1), 2009, pp. 71-83.

[12] S. Ganesan, M. George, S. Jap, R. W. Palmatier, B. Weitz. "Supply Chain Management and Retailer Performance: Emerging Trends, Issues, and Implications for Research and Practice", Journal of Retailing, Vol. 85 (1), 2009, pp. 84-94.

[13] P-L Wu, S-S Yeh, T C Huan, A G Woodside. "Applying complexity theory to deepen service dominant logic: Configural analysis of customer experience-and-outcome assessments of professional services for personal transformations". Journal of Business Research, Vol. 67, 2014, pp. 1647-1670.

[14] T Levitt. The Globalization of Markets. Boston: Harvard Business Review, 1983, pp. 92-102.

[15] D G Rutherford. Hotel Management and Operation. Washington State University, 1989.

[16] P. Kotler. Marketing Manajement: Analysis, Planning, Implementation, and Control, Manajemen Pemasaran, ed. 6. Jakarta: Erlangga, 1996.

[17] O A Yoeti. Strategi pemasaran hotel [Hotel marketing strategy] (3rd ed). Jakarta: Gramedia, 2004.

[18] A. Morrison and N. Wearne. Hospitality Marketing. Oxford: Butterworth-Heinemann, 1996, ISBN 978-0750626880

[19] B.H. Schmitt. Customer Experience Management. New York: John Wiley \& Sons, Inc., 2003, ISBN 978-0471237747.

[20] D Peppers and M Rogers. Return on Customer: Creating Maximum Value from Your Scarcest Resource. Singapore: Cyan Books and Marshall Cavendish, 2005, ISBN 9781904879343.

[21] S Diller, N Shedroff, D Rhea. Making Meaning: How Successful Business Deliver Meaningful Customer Experience. San Francisco: New Riders, 2005, ISBN 978-0321552341.

[22] P Kotler and G Armstrong. Principles of Marketing (Ninth Edition). New Jersey: Prentice Hall Inc., 2001, ISBN 9780130263124

[23] R D Blackwell, P W Miniard, J F Engel. Consumer Behavior, 10th edition. South-Western College Pub, 2005, ISBN 9788131501849.

[24] A Parasuraman, V A Zeithaml, A Malhotra. "E-S-QUAL: A MultipleItem Scale for Assessing Electronic Service Quality". Journal of Service Research, Vol. 7 (3), 2005, pp. 213-233.

[25] M Wolfinbarger and M C Gilly. "eTailQ; Dimensionalizing, Measuring, and Predicting Retail Quality". Journal of Retailing, Vol. 79 (3), 2003, pp. 183-198.

[26] V A Zeithaml, A Parasuraman, A Malhotra. "Service Quality Delivery Through Web Sites: A Critical Review of Extant Knowledge". Journal of the Academy of Marketing Science, Vol.30 (4), 2002, pp. 362-375.

[27] M L Meuter, A L Ostrom, R I Roundtree, M J Bitner. "Self-Service technologies: Understanding Customer Satisfaction with TechnologyBased Service Encounters". Journal of Marketing, Vol.64(3), 2000, pp. 50-64.

[28] A E Lloyd and S T K Luk. "Interaction behaviors leading to comfort in the service encounter". Journal of Services Marketing, Vol.25(3), 2011, pp. 176-189.

[29] T H A Bijmolt, H J. van Heerde, R G M Pieters. "New Empirical Generalizations on the Determinants of Price Elasticity". Journal of Marketing Research, 42 (May), 2005, pp. 141-56.
[30] Xiang Pan and V Shankar. Meta Analysis of Regular Price, Deal, Promotional Price Elasticities. Working Paper, University of California, Riverside, CA, 2008.

[31] S A Neslin, Dhruv Grewal, Robert Leghorn, Venkatesh Shankar, M L Teerling, J S Thomas, P C Verhoef. "Challenges and Opportunities in Multichannel Customer Management". Journal of Service Research, Vol.9 (2), 2006, pp. 95-112.

[32] R Yan. "Profit Sharing and Firm Performance in the ManufacturerRetailer Dual-Channel Supply Chain". Electronic Commerce Research, Vol.8, 2008, pp. 155-172.

[33] T Ambler, C B Bhattacharya, J Edell, K L Keller, K N Lemon, V Mittal. "Relating Brand and Customer Perspectives on Marketing Management". Journal of Service Research Special Issue: Customer Equity Management, 5 (August), 2002, pp. 13-25.

[34] R P Leone, V R Rao, K L Keller, A M Luo, L McAlister, R Srivastava. "Linking Brand Equity to Customer Equity". Journal of Service Research, 9 (November), 2006, pp. 125-138.

[35] K L Keller and D R Lehmann. "How Do Brands Create Value?" Marketing Management, 12 (May/June), 2003, pp. 26-31.

[36] S Clatworthy. "Bridging the gap between brand strategy and customer experience". Managing Service Quality, Vol.22(2), 2012, pp. 108 - 127.

[37] C Gentile, N Spiller, G Noci. "How to Sustain the Customer Experience: An Overview of Experience Components that Co-create Value with the Customer". European Management Journal, Vol.25, Issue 5, 2007, pp. Pages 395-410.

[38] C Meyer and A Schwager. "Understanding Customer Experience". Harvard Business Review, Vol 85 February, 2007, pp. 117-126.

[39] L L Berry, L P Carbone, S H Haeckel. Managing the Total Customer Experience. MIT Sloan Management Review, Sping 2002.

[40] B J Pine and J H Gilmore. The Experience Economy. Boston: Harvard Business School Press, 1999, ISBN 978-0875848198.

[41] H Mano and R L Oliver. "Assessing the Dimensionality and Structure of the Consumption Experience: Evaluation, Feeling, and Satisfaction" Journal of Consumer Research, 20 (December), 1993, pp. 451-466.

[42] R Oliver. "A conceptual Model of Service Quality and Service Satisfaction: Compatible Goal, Different Concept". In Advance in Service Marketing and Management, Vol.2, 1993, pp. 65-68.

[43] R A Westbrook and R L Oliver. "The Dimensionality of Consumption Emotion Patterns and Consumer Satisfaction". Journal of Consumer Research, 18 (June), 1991, pp. 84-91.

[44] R W Woodruff. "Customer Value: The Next Source Fpr Competitive Advantage". Journal of the Academy of Marketing Science, Vol. 25 No. 2, 1997, pp. 139-153.

[45] H E Jr Butz and L D Goodstein. "Measuring Customer Value: Gaining The Strategic Advantage". Journal Organizational Dynamics, 24, 1996 , pp. 63-77.

[46] J P Guiltinan. Marketing Management: Strategies and Programs, 6th ed. New York: McGraw-Hill, 1997, ISBN 978-0071142557.

[47] T E Balqiah. "Pengukuran Afeksi dan Kepuasan Pelanggan: Kasus Penumpang PT Pelita Air Service". Jurnal Manajemen Indonesia, Vol. 1 No. 1, 2002, pp. 8-18.

[48] B Schmitt. "Experiential Marketing". Journal of Marketing Management, Vol. 15 (1-3), 1999, pp. 53-67. 